\title{
THE USAGE FACTORS OF CODE SWITCHING IN TEACHING INTERACTION OF ENGLISH CLASS
}

\author{
Aa Qonaatun \\ Banten Jaya University \\ Serang, Indonesia \\ aaqonaatun@unbaja.ac.id
}

\begin{abstract}
The objective of this research is to gain a deep understanding and to know the use of code-switching done by lecturers and students in interaction when learning process in English class. Sub focus in this study is to determine the factors behind the use of code switching used by both speakers and partners said that in this case the interaction between lecturers and students when learning process in English class. This research was conducted on campus of State Islamic University Faculty in second semester.This research is a qualitative research using ethnographic method. The researcher examines the factors behind the use of code switching in interaction when learning process in the classroom. The research procedure by collecting data, processing, analyzing, and then presenting data objectively about the phenomenon of code switching in the interaction of teaching in English class. The use of documents on the grounds that: for a stable source, useful as a proof, because of its scientific, non-reactive nature, and the result of document review will open up the opportunity to further expand the growth and development of knowledge of something investigated. (4) The data in the research are: words, phrases, and sentences from informants as mentioned above. Data collection techniques are: (1) Observation. The tool used to assist this observation is the tape recorder. (2) Interview. (3) Documentation. The result of the research shows that there are seven factors that have been found related to the use of code switching: (1) factor of language limitations, (2) habit factor, (3) factor explaining something, (4) reflex factor, (5) base factor (entertainment), (6) factors of concern, (7) factors influenced by good speech partners between lecturers with students or students with other students.
\end{abstract}

Keywords: Factors, code switching, teaching interaction, English class.

\section{INTRODUCTION}

Code switching has become an interesting phenomenon to study in particular of language usage in society because it is part of development process and use multiple languages (bilingual). In general, code switching occurs in the community for two reasons: first, the speakers can merely communicate with the target language, and second, the diverse communication objectives (Gysels, 1992; cited in Duran 1994). The reasons cannot be separated from the influence of linguistic diversity in a community of people who eventually intermingled to form a mixture that can be understood by the community in other words that the people who have the language $\mathrm{A}$ and entered by other people 
who have the language $B$ so that both communities are mixed in a single community. So, naturally the language will have to pass the language development including a double to form code switching.

In teaching learning of foreign languages in this case the English language both teachers and learners must be more in using target language, especially when in interactions in teaching learning in the classroom. In order to the results of the learner more optimal and more effective. However, in reality when the interaction of the teaching in English classroom mostly still many phenomena of code switching and code-mixing occurs, it is done both by teachers and learners themselves.

Code switching is the use of two languages or more in a conversation, using two or more languages is conducted among other reasons due to the lack of information on one of the language being used is or simply to clarify and many other factors are the background for the occurrence of the phenomenon. It should have been more inevitable in the context of foreign language teaching because it will lead to a habit that is not good and has low prestige in terms of education.
Some researches on code switching and code-mixing that occurs in a bilingual class have also improved a lot over the last two decades. The research moved from educational research and classroom interaction style of language teachers. Study of code switching and code-mixing is generally housed within a sociolinguistic opportunities for researchers and linguists to study the common symptoms that occur in a bilingual society and multilingual. Code switching can be examined from various viewpoints such as form, place, patterns, and functions of code switching and codemixing itself.

Talking about code switching phenomenon automatically will intersect with the problem of code-mixing. Code switching that occurs in teaching and learning activities in the classroom, such as often occurs with varying patterns. This may be caused by the diversity of input and background of speakers (learners) in the class, especially in the university as education place. Code switching and codemixing is not only happening in a regular classroom, but also a foreign language class although formally so that class is expected 
to be dominated by the use of the language being studied.

In education, as has been described previously above either at the intermediate level or the upper level, even though university the using of code switching and code-mixing is often done by teachers and students in the classroom, it also occurs in one of the colleges in Banten namely at State Islamic University, because it is an event bilingualism which is prevalent in all levels of education such as elementary school education, secondary schools, and colleges. Furthermore, Indonesian has an important role in education for Indonesian confirmed as the language of instruction in the field of education from primary school level up to university level in various regions in Indonesia, including in Banten.

In this regard, based on the writer's observation during teaching English is often even many learners who find it difficult to learn foreign languages, but because English is so needed at this time. So, inevitably they have to master the language. To that end, particularly in Indonesian English more enhanced learning even many institutions that open up English language courses with a variety of methods they offer, that they do because they are aware that English is an international language that is often used in a variety of fields, even the book many knowledge-book in English. At the end, one of the goals of EFL (English Foreign Language) teacher, how the students speak English as much as possible, especially when they in the classroom to speak English, as the opinion of Hancock (1997: 217) that "to promote communicative competence, learners must get practice in communicative exchanges in the classroom ". So, to improve communication competence in English, teachers must do more exercises in the classroom. For that teachers should also be able to speak English fluently if learning to speak to be effective.

However, in reality both teachers and pupils/students still perform code switching or code-mixing even at the highest levels of education with a specific concentration has also, for example, in the English department. They require it to the various needs and objectives.

\section{Definition of Code Switching}

Bilingualism or we more often hear the term bilingualism, already we know that means is the using of two or more languages 
or language code. In many sociolinguistics research that examines issues of language codes must be very closely related to bilingualism.

Generally, in sociolinguistics bilingualism is defined as the using of two languages by a speaker and in its use of a bilingual must master both languages are the first language (FL) for the first language can be the mother tongue or regional language, and furthermore second language (SL) for the second language is a second language or a foreign language.

Explanation about the concept of bilingualism is always changing. The term was first introduced by Bloomfield (1988: 1) in his book "Language" states that "It is the ability to use to language equally well by a speaker as a native speaker mastering his language" bilingualism is the ability to use two languages as well as equally by a speaker of two languages or native like control of two languages, mastery of two languages with fluency and accuracy are the same as native speakers is very difficult to measure, since the definition implies that a bilingualism are bilingual equally well. And this definition is considered very heavy because someone new can be said to be bilingual if they command a second language as well as his first language.

Furthermore, the definition according to Einar Haugen (1969: 10) stated that the bilingual is defined as the ability to provide a complete and meaningful speech in other languages. If described more generally, the definition of bilingualism is the use of two languages interchangeably both productive and receptive by an individual. This definition imposes limits narrower than the definition proposed by Bloomfield due to the given constraints, namely a so-called bilingual if the person is able to speak in full and meaningful in both languages.

Further WP Mackey (1970: 554) gives a looser definition of bilingual namely a bilingual say if someone is using two or more languages interchangeably. And the circumstances faced by the bilingual helped determine a change of the language being used.

If observed from the third meaning or definition above, bilingual concept has undergone changes and simplification. This is in accordance with the opinion of Istiati (1985: 10) states that the concept of bilingualism any time getting watered. But 
even experienced simplification at the level of the definition of the concept but will not be released from the constraints of bilingualism.

Studies of code switching that are generally housed within a sociolinguistic opportunity for researchers and linguists to study the common symptoms that occur in society and the various languages are bilingual. Code switching can be examined from various viewpoints such as form, place of event, pattern, and the transfer function of the code itself. Code switching that occurred in the teaching learning in the classroom, for example, many evens often occur with varying patterns. This may be caused by such diverse input and backgrounds who are involved in the teaching and learning process, especially in teaching and learning in higher education. Code switching does not only occur in a regular classroom, but also in foreign language classes although formally so that class is expected to be dominated by the use of the language being studied.

\section{Bilingual society and multilingual} generally tend to switch codes language in their daily activity. Code switching that occurs in the community is often regarded as a strategy conversation. Sometimes these strategies in terms of influence stylistic, which relates to its use in reinforce or weaken the speech acts such as requests, denials, switching topics, elaboration or comments, validation, or clarification (Heller, 1988: 77). Symptoms of code have a value of "naturalness" for particular speech events for the community or bilingual speakers or more. According to Milroy (1999: 5) over the code is the use of multiple languages alternately by bilingual speakers / various languages.

In another part of Milroy mention that the code switching is the alternative use of two or more languages by bilingual speakers/multiple languages in one conversation. In this case Milroy see that code switching a manner or form of communication that is common place in a bilingual society and a variety of languages. In contrast, in the process of bilingual education and foreign language code switching is not familiar and natural as in society bilingual/multi-language, but more managerial. In the learning process of code to act more as a tool to manage and facilitate interaction and learning. Heller (1988: 1) plainly says that the code 
switching is the process of using more than one language in one episode of communication. In this case it does not require the balancing mastery of two languages or more by speakers who is switching of codes.

\section{Factors of Using Code Switching}

Code switching and code-mixing are sociolinguistic phenomena which have similarities. Therefore, the factors driving the occurrence of these two events are also difficult to distinguish and often overlap. Some experts also specify the factors are varied. Indra stated, "There are several reasons why someone bilingual to transfer code. Some of these reasons include: 1) quotes from someone; 2) affirmation of group identity or solidarity; 3 ) to enter or exit a person of a conversation; 4) raise the social status; 5) demonstrate proficiency".

Indra draw up its own classification of the factors that encourages code-mixing. Noted in a study that outlines the factors driving the mixed code is divided into two, namely (1) extra linguistic and (2) intra linguistic. Extra linguistic factor is influenced by things outside of language. For example, in relation to the purpose of the conversation, the conversation situation, level of education, social status, interlocutors, and the nature of the talks. Extra linguistic factors may also arise from the desire of speakers to explain, declaring prestige, jokes, using language that are metaphors, and other causes. Intra linguistic factors associated with things that exist in the language itself. For example, the absence of the lexicon of the native language for certain concepts, native language lexicon yet or not make a concept that mentioned in other languages, and other causes.

Meanwhile, according to Suwito (1983) the factor of code switching contributing to the control of the code is as follows:

\section{Speakers}

A speaker sometimes deliberately switches the code on the hearer as a destination. For example change the situation of the official becoming unofficial or otherwise.

\section{Interlocutor}

The partner that has same linguistic background with speakers; usually in the form of a code switch over the variant and when hearer different linguistic 
backgrounds tend switch in the form of code interpreter.

\section{The Presence of the Third Speakers}

To neutralize the situation and respect the presence hearer; third, usually the speaker and hearer switch codes, especially if they are different linguistic backgrounds.

\section{The topic}

a. The principal topic of conversation or a dominant factor in determining the transfer code.

b. The topic is usually in formal expressed with the standard variety, with serious and neutral style and the informal topic non-standard delivered with the language, the style a little emotional, and completely arbitrarily.

\section{To generate a sense of humor}

Usually done with switching variants, rather wide, or rather a way of speaking.

\section{For prestigious}

Although the factors of situation from the partner, topic, and the socio factors do not expect any code switching, occurred over the code, so that it looks coercion, unnatural and tend not communicative.

In addition to the above explanation of the main factors causing the speakers to use English in their speech element is due to bilingualism. It is the opinion of the Weinrich, suggests bilingualism as the use of two languages (by someone) interchangeably. Someone often uses or mix the language with other languages because he masters either actively or passively in both languages.

\section{Teaching English}

The teaching of foreign languages as part of language acquisition (language acquisition) designed and performed programmatically. As belonging to the realm of second language acquisition.

In the world of language teaching, terms such as mother tongue, first language, second language, foreign language, language acquisition, language learning, and others often appears with a variation of the concept is quite diverse. Although the basic concept remains the same, but the development and interpretation often raises various issues as well. In this case Stern (1994: 24) argues that, fundamentally, the 
Universitas Banten Jaya

first language (mother tongue) is a language that is controlled by someone my rent small and early childhood prior to mastery (and use of) other languages. The first language is also understood as the language that was first obtained and the dominant language is used. Second language, on the other hand, is the language obtained or to be obtained much later than the first language. Foreign language is a language that comes from outside the region use the first or second language is deliberately studied in more formal or organized academically.

The basic concept of the first language, second language and foreign language as stated above should be known by language teachers, good teachers in Indonesian language, a second language or a foreign language. Teachers need to develop a language of teaching and learning activities in the classroom by observing the status of language teaching. Although there are fundamental similarities of the three types of teaching and learning the language, but that can not be avoided is that all three distinctly different. Therefore, teaching English in Indonesia, for example, can not be equated absolutely with the teaching of Indonesian language. This is where the role of the language teacher really determines the success of the process of language teaching in the classroom learns some vital lessons. Murphy and Byrd in Mattioli (2004: 21) says that the English language can be referred to as a second language (English as a Second Language / ESL) in a country where English is the primary language of commerce and education, where students (students in university) are often hear English used regularly outside the classroom.

Otherwise English will be a foreign language (English as a Foreign Language / EFL) in countries where the above conditions do not exist. The students (students in university) mostly only hear English used in the classroom or once in a while outside the classroom and it was very limited. Thus, the meeting in the classroom is the only opportunity to learn, use, or practice the language. Based on this Teaching English as a foreign language in Indonesia has some problems. The most frequently expressed by the mass media, government, teachers, and parents is the lack of English language skills of students and students of Indonesia. Government disappointed because any applied 
curriculum have not been able to improve the understanding and value of English student/student. Teachers / lecturers are also disappointed for a variety of teaching methods and strategies have been used, but the results of student learning / student has not been satisfactory. The parents are confused because after six years of learning the English language, there are even more, their children can not speak English. The learner itself is no less confused because after studying for so long they can not speak English well.

In the neighborhood or country where English is studied as a foreign language, students' intrinsic motivation is usually low. English is considered irrelevant for students because not become part of his daily life. English language lesson is learned only due to become compulsory in schools. The number of students in the classroom is usually very much, while the clock-face is very limited. It does not give a chance exposure (exposure) sufficient language to students. This will not happen in an environment that uses English as a second language. In such an environment the student intrinsic motivation is high because the English language is relevant to their daily lives. They should be able to speak English to be able to 'survive'. Moreover, because of living in an environment that uses the English language, they have many opportunities to use English and see the results immediately.

Motivation is one of the most important factors in learning the language, let alone a foreign language. Therefore, teachers / lecturers of English as a foreign language has been and always trying to find new approaches or strategies to increase learner motivation in participating in learning English. Unfortunately, many students / pupils do not like to learn English; and although they were present in the classroom, they are not interested to participate talk. They just want to pass the exam (albeit with a modest value).

Research (1999: 17) at the School of Nursing in Holguin also shows that the students are not interested in learning English because they feel there is no relationship between the English with their later careers as nurses. They think, they will serve is its own citizens who do not speak English. In a country that has a state and an atmosphere of learning English as in Indonesia, for example, needed 
psychological and emotional impulse that invites learners knowingly and voluntarily willing to learn in earnest. Researchers and experts in language teaching (second and foreign) have put forward many tips for the motivation of the learner.

One of them McKay (2004: 10-15) chooses cultural approach to stimulating learners. According to him, forming a positive attitude towards culture native English speakers will often encourage students to learn the language. Instead, Mattioli (2004: Vol 4) suggests that the use of mother tongue learner can cause motivation to learn English. By creating a communicative classroom atmosphere learners will feel very happy to learn and have the desire to optimize its capabilities. Many other tips that may be used in the English language learners to overcome difficulties in countries such as Indonesia.

Sociolinguistic research is a study of great interest by linguists. This may be caused by the phenomenon that both the language and social life and culture in the community are dynamic that is always moving nature. The dynamics of the nature makes the researchers in the field of language interested to examine it. One of them is about the code switching because the study is under a sociolinguistic field, following some previous research on the code switching in the interaction of teaching in English classes relevant to this research.

Christa van der Walt (Stellenbosch University) Conducting the research under the title "The Functions of Code Switching in Learning Language Classes", the objective of the research is to know the function of code switching by lecturers in teaching English in the classroom. Specifically this study aims to find out (1) the form of code switching used, (2) the type of code switching, (3) the code switching function, and (4) the factors causing the use of code switching by lecturers in language teaching English courses in English education in the classroom.

\section{Sitti Maryam Hamid (English}

Education Department, Faculty of Teacher Training and Education Muhammadiyah University of Makassar), Conducting her research under the title "Code-Switching Between the Teachers and the Students of the Conversation", the research findings from this study indicate that teachers do code switching in classroom conversations. The English teacher uses English and Bahasa Indonesia in teaching. English teachers use code transfer to (1) ask questions, (2) show unpleasant feelings, (3) to reinforce requests or orders, (4) to clarify 
messages, (5) to give advice, (6)) to creating humor, while students use code switching in order to make them easy to speak English and easy to understand what they want to convey. Switching the code from English to Indonesian or other languages can also be used as a communication strategy in an English conversation class. English teachers use code switching to minimize students 'mistakes in understanding students' lessons or difficulties in understanding the English lessons provided by English teachers in the classroom.

\section{Engku Haliza Engku Ibrahim} (International Islamic University Malaysia, Malaysia) Doing his research under the title "Code-Switching in English as a Foreign Language Classroom: Teachers' Attitudes". This study examines teacher attitudes

\section{METHOD}

This study is a qualitative research with the intent to collect the data, process the data, analyze data, and present data objectively about the interaction of code switching in teaching English to students of English Education Department of State Islamic University. Thus, the exact method used in this study is an ethnographic method toward code switching in teaching English as a foreign language for Malay students at a local university in Malaysia. Data were collected through observation, questionnaires and interviews. Each teacher was observed, the use of their language recorded, transcribed and then analyzed using qualitative descriptive method. The results of the study indicate that teachers have transferred the code in the language class, with the aim of delivering the material, (b) class management, and (c) the discourse marker. With reference to these functions the use of code switching in learning English can be done as long as it is intended to fulfill the academic function. In line with the increasing English language ability of learners, the use of code switching needs to be reduced. of communication based on the theory Hymes developed by Saville-Troike with a pragmatic approach. The procedure of research by observation, recording, transcription of data, the analysis of data, and a research report.

The primary data that used is the phenomenon of code switching in teaching learning interactions that occur when teaching and learning process of English 
class in English Education Department of State Islamic University. The primary data source is the English Department student interaction in English class. Meanwhile, secondary data are books or documents relevant to the focus of research.

\section{Data Collection}

Procedures and data recording is an effort made to obtain data in the field. It requires a variety of ways in order to achieve the research objectives. The procedure of collecting the data through observation, recording, and interview.

\section{Observation}

As a method to obtain the data field with the following techniques :

a. Participant observation, the researchers participate and show sympathy that the studied subjects are not bothered. This is done so that all events that occur can be observed well and gained as much data as possible.

b. Descriptive observation that investigators conducted a thorough observation of the various things that felt, seen and heard in relation to the events of code switching and code-mixing. c. Focused observation is focused observation that researchers identify and learn as much as possible partial or cultural behavior that occurs in the faculty of education and teaching of State Islamic University.

d. Observations elected the chosen observation that prepare researchers conducted observations with careful planning. In this case, the researchers conducted observations and have some general questions.

\section{Records}

Collecting data in the field is done by recording happens the lecture in the classroom. Recording the data obtained as the main data in the process data of this study.

\section{Interview}

The interview is only a supporting data to complement the data that have been found through direct observation. That is, to supplement the data obtained in the field through direct observation regarding recording or code switching and codemixing. This is done so that the data obtained are completely accurate. The data obtained in the field were analyzed based on 
the Hymes's theory of the three units related to communication analysis as presented in the literature review that situation communication, events communicative and communicative action. Researchers conducted an analysis of the communicative event that includes all the component.

\section{DISCUSSION}

Source of data in this study is a narrative of the events of interaction when teaching-learning process in an English class at the English Education Department Faculty of Education and Teaching of State Islamic University. Data was taken from the second semester students of English class, the following are some data that the authors cited as the source of the data and then will be analyzed and discussed.

\section{Data 1}

L : conversation, grammar and just practice. Okay. I you read, if you have read the paper, this is talking about what is it?

$\mathrm{S}$ : Wishes...about ee...hope about

$\mathrm{L}$ : ee..if I wish, If I will...I become...apa sih di SMP itu istilahnya?itu apa itu istilahnya?

Conditional sentence

Ya...conditional If ya?

Conditional

sentence...right..conditional

sentence. That is about conditional. So, have you read the conversation?

\section{Data 2}

$\mathrm{S}:$ tomorrow they will have exams

L : Okay...tomorrow they will have exams. And they are...they..what is it...they feel nervous and they try to make wish...andai andai gitu ya.. apa

$S$ : ya istilahnya andai andai. Ya something like wish and the sentence use conditional if... Nah show me the sentence in this conversation..yang mana kalimatnya?

If I'm nervous about something, I tried not to think about it...

\section{Data 3}

L : I'm fine too thank you...so where are others? Yang lain

$\mathrm{S}$ : mana? I don't know...

\section{Data 4}

S1 : Yeah is have eleven rules. The first when the subject of a sentence is compose of two or more nouns connected by "and" use a plural verb. Jadi

Ss : ketika kalimat..dalam sebuah kalimat terdiri dari perpaduan antara subjek...eh entar dulu...ya ketika subjek dalam kalimat itu ee...kalimat dalam sebuah

Apa?(saying something)

Data 5

L : Coba dependent nya..ya itu kan yang bisa berdiri sendiri..coba

$S$ : yang ga bisa berdiri sendiri Ya...yang ga bisa berdiri sendiri kakinya jatoh...(Giggling)

Data 6 
L : Now I want you to open page 50..page 50...write the concluding sentence for the following paragraphs..pargraph one and paragraph two... Okay..paragraph one paragraph two..Noah I want

$\mathrm{S}$ : you..I want you to do it on a piece of paper..and we'll consider it as you first quiz...quiz pertama.silahkan dikerjakan di kertas. Lalu di kumpul kan. Don't forget to write down your name and to write down "first quiz".

Only the answer?

Data 7
L : Ya..next week...no class ya..kebeneran minggu depan pas minggu tenang ya? So we meet again at mid semester ya? Don't forget to ask information about it. Jangan lupa ditanya informasi tentang uts nya seperti apa, di ruang
S : berapa.Kalau harus kembali seperti semula ya..berarti anda siap siap kita ujiannya di ruang dulu, yang kita tinggalkan itu and then jam nya...
ada jadwalnya

Data 8

L : Nah if you have done with your work, put your work

S : here..collect to me..

L : Not yet..

Not yet? For those who have

$S$ : already finished you may

$\mathrm{L}$ : collect your work to me and

$\mathrm{S}$ : then you may go home.

Miss ini yang waktu itu.. yang mana? yang waktu gabung sama kelas lain itu..

Data 9

L : Okay, sometimes a concluding sentence reminds the readers of the points in topic sentence. $\mathrm{Di}$ ulang lagi di ulang lagi ya..sama aja dengan yang pertama kali di pelajarai dulu ya. So di pharaphrase ya...kalimat yang di atas itu topic sentence nya,

$\mathrm{S}$ : topic sentence, supporting

L : sentence terus di akhir nah topic

$\mathrm{S}$ : tadi di summary di pharaphrase dengan bahasa yang berbeda di pharaphrase. Jadi di singgung sedikit ya yang topic sentence nya tadi untuk dijadikan sebagai concluding sentence..

Sentence

Sentence not senten senten

Sentence

Data 10

L : Under the tree? Eating breakfast under the tree? O...yes they are...pantesan di tutupi pake gorden...jadi ga keliatan. okay today we continue the lesson...please open your book page 53...sentence structure....Sentence structures, compound sentences page 53.

$\mathrm{S}$ : Have you found? $\mathrm{O}$ yes... So look at the box...compound sentence is two sentences connected by a comma and a coordinating conjunction. So I believe that you still remember about simple sentence, right? Simple sentences...apa syaratnya?

Ada subject..(Together) verb, object 
Data obtained from the results of this study show the events the use of code switching is done either by teachers (lecturers) and student interaction in class for learning in English class based on the results of these studies researchers found several background factors occurrence of code switching they are: (1) factor of limitations of language, (2) factor of habitation, (3) factor of explaining something, (4) factor of different of topics, (5) the factor of entertainment, (6) the factor of worries, (7) the factors of affected by the partner both of lecturers and students or students with another.

1. Factor of language limitation/ knowledge

In interaction when learning activities take place in an English class should ideally either lecturer or students should have the language of instruction is English, but for students as learners still limited ability to use the English language once in a while even frequently use the Indonesian language, it is occurs naturally because the position of English language as the target language that they are studying.

Thus, when the interaction of the learning takes place both lecture and students still use the Indonesian language, as long as it is not excessive, the rule just flows without the written provisions. To factor these language limitations usually it is characterized by the expression of the use of interjection "emmhhh ..." indicating that the speaker does not know the language he would say in English, so they immediately express in Indonesian. To these factors we can see in the first speech, the speech following "conversation, grammar and just practice. Okay. I you read, if you have read the paper, this is talking about what is it? Wishes...about ee...hope about ee..if I wish, If I will...I become... apa sih di SMP itu istilahnya?itu apa itu istilahnya?"Indicates that the speaker does not know a term in English to be spoken as well as reveal the speakers switch their speech code switch into Indonesian. That is because the speakers are limited in terms of language knowledge thus affecting also disclose their speech.

\section{Factor of habitation}

Form of code switching and codemixing caused by that habit also very often the case when the interaction in learning activities take place and usually to factor this practice occurs at the beginning or end 
of study or frequent in the use of language classes, which are frequently used in everyday life that have become habit. Because these habits both lecturers and students do not feel uncomfortable or felt he had done something less than ideal, and the expression of their normal use. Almost all speech to factor these habits of speech are switching code of their speech because the speech make a pattern and its said repeatedly, the speech which usually includes the word "aha,, yes ,, so ,,, and so on" speakers often pronounce the word as customs and spoken with continue to use Indonesian.

\section{Factor of explaining something}

Learning activities have one goal which is to convey information about a science or a related learning theory they are studying or explaining something related to learning materials. When in delivering learning materials is expected that all learners understand, but because of the language of one of them which could be a barrier for students to understand the learning material, to that a teacher can do a code switching and code-mixing into Indonesian so that learning materials can be absorbed good. For that interaction we can be seen in the fourth speech, speakers discussed the lecture's material in English but then switch code using Indonesian language when going to explain for more detail based on their understanding by using Indonesian, means here to transfer the code because it will explain the material.

\section{Factors of entertainment}

To make fresh the situation and reduce boredom in the classroom both lecturers and students usually use the expression joke, for those jokes phrase sometimes even their frequent switch code into Indonesian, they feel better and more excite if use their mother language that is based on interviews of some students. That interaction can be shown from the fifth speech, the speech of the speakers switch codes when trying to joke with the opponent he said and expressed by Indonesian.

\section{Factor of fears (worried)}

In teaching learning has become something usual lecturer explains the material, in explaining the material in English class the lecturers are required to use English as the target language being studied. However, as explained by using the target language lecturers sometimes worried that his students or his opponent said not 
understand the intent and purpose of explanation and it is feared the purpose of learning is not delivered or is misunderstanding between speaker and hearer. At the end, the speakers do over the coded into the source language. For the speech we can see in the seventh speech, in the speech of the speaker talk with English but suddenly switched the code into the Indonesian language that essentially just repeat these words, it means here the speaker worried that the partners did not understanding with his speech in English when he said, although his partners have not declared whether they understand or not.

\section{Factor of affected by the partners}

To honor the hearer in interact sometimes we have to follow what language is used by us as did the partner said when learning takes place in the classroom, on the basis of the common events of code in an interaction caused affected by the hearer/partners. As seen in the eight speech, in the speaker's speech switch code into Indonesian because he said partners also use the Indonesian language, it can be said they switched because the code affected when interacting with each other.
Code switching can be occur because the different topic. Thus, the speaker deliberately switch code using Indonesian when speaking in English language learning in the classroom only to distinguish the subject. As shown in part by the tenth data on the " Under the tree? Eating breakfast under the tree? O...yes they are...pantesan di tutupi pake gorden...jadi ga keliatan. okay today we continue the lesson...please open your book page 53...sentence structure....Sentence structures, compound sentences page 53. Have you found? O yes...So look at the box...compound sentence is two sentences connected by a comma and a coordinating conjunction. So I believe that you still remember about simple sentence, right? Simple sentences...apa syaratnya?"In a speech that the speaker switch code into the Indonesian language when talking about the condition of the students at that time and then re-use the English language to start the course, it is to distinguish that speakers use the Indonesian language when talking about something that is not nothing to do with the material.

\section{Factors the difference topic}




\section{CONCLUSION}

Based on the discussion of the data that has been analyzed and discussed above regarding the factors that cause these interactions using the code switching in teaching learning English in the classroom. So, the conclusions obtained are as follows: There are seven factors that cause code switching when the learning takes place in English classroom they are factors of limitations language, factors habit, fear factor, factor because different topic of conversation, entertainment factor, a factor influenced by the hearer/partner, and the factors explaining something / one term.

Based on situations and conditions that can trigger the emergence of code transcripts recommended for students and lecturers, this research can be an input in determining language attitudes associated with the use of code transfer and code mixing especially when in teaching and learning of English class.

Based on situation that can trigger the emergence of code switching is recommended for students and lecturers, this research can be an input in determining the attitude of language related to the use of code switching, especially when in teaching and learning situation in English class.

Use of code switching and code mixing is appropriate for using in bilingual classes. Further research is expected to carry out other similar research, the research related to the use of code switching and code mixing interfacing with the process of language teaching, the attitudes of the language users to the practice of code switching and code mixing, can also examine the relationship of the use of code switching and code mixing with the level of language development and language acquisition.

\section{REFERENCES}

Bloomfield, Leonard. Language. New York: Holt, Rinehart and Winston, 1988.

Christa van der Walt (Stellenbosch University), Journal for Language Learning Perlinguagm 200925 (1): 30-43 http://dx.doi.org/10.5785/25-1$\underline{27}$.

Engku Haliza Engku Ibrahim (International Islamic University Malaysia, Malaysia), English Language Teaching; Vol. 6, No. 7; 2013. Published by Canadian Center of Science and Education. doi:10.5539/elt.v6n7p139. 
Gyl, Mattioli. "On Native Language Intrusions and Making Do with Words: Linguistically Homogenous Classrooms and Native Language Use." English Teaching Forum. Vol. 42 No. 4, October 2004.

Hancock, M. Behind classroom codeswitching. Layering and language choice in L2 learner interaction. TESOL Quarterly 31 (2), 1997.

Haugen, E. The Norwegian language in American: A Case Study in billigual behavior. Bloomington: Indiana university press, 1969.

Heller, Monica (Editor). Codeswitching. Berlin: Mouton de Gruyter, 1988.

Indra, I.B.K. Faktor Pendukung Terjadinya Campur Kode dalam Pementasan Drama Gong di Bali. Aksara, XIX (31), $35-43,2008$.

Jendra, M.I.I. Sosiolinguistics. Yogyakarta: Graha Ilmu. 2001.

Kentjono, Djoko (Ed). Dasar-Dasar Linguistik Umum. Jakarta: Fakultas Sastra UI.1982.

Mackey, W.P. 1070. The Description of Billinualism. Dalam J.A Fishman (Ed.)

Martin-Jones, Marylin."Code-switching in the Classroom." Dalam Milroy, Lesley \& Peter Muysken (Editor.). One Speaker, Two Languages. Cambridge: Cambridge University Press. 1995.
Sitti Maryam Hamid (English Education Department, Faculty of Teacher Training and Education Muhammadiyah University of Makassar), Exposure Jurnal. Vol. 5 No. 2 November 2016. http://dx.doi.org/10.26618/ejpbi.v5i2.8 $\underline{46}$.

Suwito. Sosiolinguistik: Teori dan problema. Surakarta: Kenary offset. 1983.

Stern, H. H. Fundamental Concepts of Language Teaching. Oxford: Oxford University Press. 1994.

Winreich, Uriel. Languages in Contact: Finding and Problem. New York: Mouton Publishers the Houge.1963. 